\title{
The Impact of Non-Performing Loans on Firm Profitability: A Focus on the Nigerian Banking Industry
}

\author{
Dr. Joseph Femi Adebisi, Phd, FCNA, ACTI, MNIM, MACFEI ${ }^{1}$, Okike Benjamin \\ Matthew, Bsc. M. Sc., CNA ${ }^{2}$
}

Nigerian College of Accountancy, Kwall near Jos, Plateau State, Nigeria

\begin{abstract}
The study considered the impact of non-performing loans on firms' profitability of banks in Nigeria. The increased incidence of non-performing loans (NPL) in Nigerian bank generated the current literature on quality of banks profitability. Though there have been reforms in the banking industry to ensure effective financial institutions, the banks shareholders funds are affected by the non-performing loans. This study made use of secondary data obtained from the Annual Report and Statement of Accounts of the NDIC for a period of seven (7) years (2006- 2012). Data were analyzed using the regression statistical tools. The first result revealed that there is no relationship between the Non-performing Loans (NPL) and Return on Assets (ROA) of Nigerian Banks. This means that the asset values of the firms are not affected by the level of NPL. The shareholders wealth maximization is affected as second result showed that there is a relationship between the Non-performing Loan (NPL) and Return on Equity (ROE) of Nigerian Banks. It is recommended that the banks should ensure that the banks customer has viable means of repaying the loan, which should be monitored to ensure efficiency.
\end{abstract}

Keywords: Non-performing loans, banking industry, return on assets, return on equity.

\section{INTRODUCTION}

Every good economic system of a country is highly dependent on a sound financial system. No good financial system can do without well-structured and efficient financial institutions specifically the banking industry. Khan and Senhadji, (2001) opined that poor performance of these institutions does not only affect the economic growth and structure of the particular country but also affects the entire world. In his opinion good performance of these financial institutions is represented by affluence and economic growth in any country or region. One of the main functions of financial institutions is to link the surplus and the deficit units in an economy or financial intermediation. Bossone (2001) opined that the banks intermediation services are exceptional because of their unique ability to finance production by lending their own debt to agents willing to accept it as one of its sources of fund. De Santis and Surico (2013) states that banks are best placed to refinance the real economy, in particular the small- and medium-sized firms, which are the biggest providers of employment in the economy. Also the commercial banks play a critical role in developing economies where most borrowers do not have access to capital markets (Greuning and Bratanovic, 2003).

The efficiency of the bank's performance is a function of how they are able to satisfy their customers at a minimum risk level and maximum profitability level. One of the risk factors is the non-performing loans granted by these banks. This is why the issue of non-performing loans cannot be over emphasized.

Non-performing loan are those loans that are not paid up as at when due. Caprio and Klingebiel (1996)), suggest that non-performing loans are those loans that do not generate income for a relatively long period of time that is, the principal and or interest on these loans have been left unpaid after due the dates of repayments. Hennie (2003) argued that non-performing loans are loans that are not generating income. Mostly the banks make their profits from interest paid on loans granted to the deficit units of the economy. Yet some of the customers granted these loans fail to meet their contractual obligations of repaying the loans or even paying the interest element of the loan.

The problem this research aims to address are; first, the how non-performing loans have largely affected the wealth maximization of shareholders fund, the profitability of the banks as well as saving of depositors. Secondly; Nonperforming loans have caused the liquidation and takeover of many banks all around the world. Some Nigerian

${ }^{1}$ Corresponding Author: benthew2000@gmail.com 
banks such as Intercontinental bank, Oceanic bank, BankPhB and Afri-Bank just to mention but a few, have been affected by incidences of non-performing loans in Nigeria. There are evidences that even among banks that do not

fail, there is a negative relationship between the non-performing loans and performance efficiency Subaru, Kuku (2010) Nafiu and Omankhanlen (2011) Mohammed (2012) Kwan and Eisenbeis (1994), Hughes and Moon (1995), Resti (1995). This necessitates the need for this research to analyzed and determine the measure to which nonperforming loan affects profitability in the Nigerian Banking industry.

This study is very imperative to the financial regulatory authorities, bankers and their stakeholders and policy makers in Nigeria for the purpose of fast tracking the development in the Nigerian banking industry and the economy at large. Given the significance of the study, the objective of the study is to analyze and determine the extent to which non-performing loans had affected profitability in the banking industry (Commercial, mortgage, and community banks) in Nigeria.

In other to resolve the above stated problems and to achieve the objectives of the research, the following hypotheses stated in their null format were tested:

Hypothesis I: There is no significant relationship between Non-performing Loans (NPL) and Return on Assets (ROA) of Nigerian Banks

Hypothesis II: There is no significant relationship between Non-performing Loans (NPL) and Return on Equity (ROE) of Nigerian Banks

\section{LITERATURE REVIEW}

In order to establish the uniqueness of this research work we shall put into consideration the various previous researches in relation to the subject matter.

Rajan and Dhal (2003) research on Non-performing Loans and Terms of Credit of Public Sector Banks in India; they found that favourable macroeconomic conditions and financial factors such as banks size, cost of credit, credit maturity, and credit orientation have significant impact on the non-performing loans of Indian commercial banks.

Jimenez and Saurina (2005) examine the Credit cycles, credit risk, and prudential regulation of Spanish banking sector from 1984 to 2003. The study provides evidence that non-performing loans are function of Gross Domestic Product (GDP) growth, high real interest rates and lenient credit terms. The study further revealed that disaster intolerance, herd behaviour and agency problems may entice bank managers to grant loans excessively without adequate analysis during boom periods may contribute to non-performing loans.

Joseph, Edson, Manuere, Clifford\& Michael, (2012) investigated the causes of non-performing loans in Zimbabwe. The research revealed that external factors are more prevalent in causing non-performing loans among Zimbabwean banks. The external factors which include natural disasters, government policies and the integrity of the borrowers have been identified as the major or predominant causes of non-performing loans in Zimbabwean banks.

Khalid A. (2012) examines the effects of loan quality on bank performance. Using the multiple regression models to analyze; the return on assets and profitability ratios as proxies for banks profitability between the periods of 2006-07 and 2010-11 were under consideration. The results support the hypothesis that the higher the quality of the loan processing activities before loan approval, the lower the non-value-added activities that is required to process problematic loans, and thus the higher the banking operating performance will be.

Abdullahi S. (2013) investigated the efficiency of credit risk management on banks performance, also to determine if credit risk has effect on the profitability and examining the relationship between interest income and bad debt (non-performing loans) of Union Bank PLC. The research revealed that credit risk affect the performance of banks and for the banks to maintain high interest income, adequate attention should be given to credit risk management specifically the lending philosophy of banks. The study recommends that bank loans should be adequately reviewed from time to time to assess the level of risk and every loan should be secured with collateral.

Nir Klein (2013) in An International Monetary Fund (IMF) Working Paper investigates the non-performing loans (NPLs) in Central, Eastern and South-Eastern Europe (CESEE) covering 1998-2011. The paper reveals that the NPLs level can be ascribed to both macroeconomic conditions and banks' specific factors, even though the banks' specific factors was found to have a relatively low explanatory effect on NPLs. It further reveal that NPLs were found to respond to macroeconomic conditions, such as GDP growth, unemployment, and inflation which means it affects the economic recovery of the region. 
Given the above review of past researches this research work is unique since none of the above mentioned investigations took a cross sectional look at the banking industry in Nigeria.

\subsection{Intermediation Function of Banks}

Ayo (2002) opined that there is distinction between the surplus and the deficit units of an economy which makes savings irrelevant to investment mechanism. This makes necessary the presence of intermediate institutions that create a link between the surplus and deficit units. The financial institutions play unavoidable role in bringing the surplus unit with the deficit units together to promote investment activities in an economy. The intermediation function of the financial institution involve the lending of funds collected in form of deposits, insurance premium and savings to the investors for a return referred to as interest. Revenue generated from interest is a major source of income to the financial institutions. Most of these financial institutions have not been diligent in disposing loans to these investors which result to non-performing loans.

\subsection{Loan in the Banking Industry}

One on the primary function of the banks is the provision of loan to its customers; as such it is almost impossible for any bank to operate without lending money to its customers. Banks are seen as major players in economic development of a nation since the control the flow of fund in the economy. For the banks to play their role in economic development they make funds available to investors who do not have enough resources to fund their business ideas. The loans are provided at a consideration called interest. To ensure that the customers stay faithful to their obligation of repaying the loan along with the interest element the banks ask of collateral. The collateral is a sort of security on the loan to avoid lost of fund by the banks. In other to further buttress the relevance of collateral, let look at the types of loan. We have three types of loan which are:

Secured Loan: A secured loan is a promise to pay a debt, where the promise is "secured" by granting the creditor a right on a specific property (collateral) of the debtor as leverage for repayment in the event of default. Where the debtor fails to repay the loan, the creditor can recoup the loan by seizing and liquidating the specific property used for collateral on the debt. Collaterals are demanded mostly if the loans are long term loans. This is the common type of loan that the bank grants because banks are general risk-averse.

Unsecured Loan: These are loans granted to customers of the bank without any right on the property (collateral) of the borrower to ensure repayments. In this case the lender is relying upon the creditworthiness and reputation of the borrower to repay the debt. This is mostly in situation of short term debt like bank overdraft also where the amount involved is not much.

Partly secured Loan: this is a combination of both secured and unsecured features. A secured debt is a loan in which the borrower pledges some asset as collateral for the loan. However, a partially secured debt is a debt that is secured by collateral that is worth less than the debt. For example, a $\$ 120,000$ house loan that is secured by a car that is now worth only $\$ 60,000$.

The best form of loan is the secured loan, because it provides a back up to that allow the bank recoup his money if the customer defaults in paying back the fund. However, despite all this measures (requesting for collateral) to control the lost of fund/income by the bank we still have cases of non-performing loans. Caprio and Klingebiel (1996)), suggest that non-performing loans are those loans that do not generate income for a relatively long period of time that is, the principal and or interest on these loans have been left unpaid after due date of repayment.

\subsection{Non-Performing Loans in Nigeria}

The non-performing loans have been a subject of concern in the Nigerian financial system for about a decade now. The excessively high level of non-performing loans in the banks can also be attributed to poor corporate governance practices, lax credit administration processes and the absence or non- adherence to credit risk management practices (Hamisu 2011). Most of the none-performing loans are caused by unprofessional ways the Nigerian bank managements disburse loans influence by personal affiliations with the customers. Rather than follow the standard procedure of granting loan as provided by the bank, they grant loans based on personal relationship with the customer who have not met the banks requirements for granting such loan. Most of these loans turnout to be nonperforming loans in the future. There are also circumstances where banks grant additional loan facilities to defaulting borrower. As a proactive measure to avert the menace of resurgence of non-performing loan and to ensure safe and sound financial system the CBN in June 2014 directed that no financial institutions shall without the prior written approval of the CBN grant a credit facility to a potential borrower who is in default of the any existing credit 
American Research Journal of Business and Management, Volume 1, Issue 4, 2015

ISSN 2379-1047

facility to the tune of N500Million and above in the case of deposit banks and N250Million and above in the case of development banks and banks in liquidation.

\subsection{Methodology}

In order to resolve the problems stated and achieved the objectives of this study, content analysis is employed. Data were collated using the secondary data collation method; the data were from the 2006-2012 Annual Report and Statement of Accounts of the NDIC downloaded from their corporate website. The regression statistical tool is used for analysis. In order to test the hypotheses the independent variable measured are the Non-performing Loans and ratio of Non-performing Loan to Shareholders' fund while dependent variables are profitability indicators which include Return on Assets (ROA) and Return on Equity (ROE).

\subsection{Data Presentation}

The objective of this section is to present, analyze and interpret the data collected for the purpose of this study. The data covers the information collected from secondary sources; 2006-2012 Annual Reports and Statements of Accounts of the NDIC. T-test and correlation statistical tools are used to analyze and presents the findings for easy understanding.

Non-Performing Loans, Total Loans Granted and Total Assets of Nigerian Banks

\begin{tabular}{|c|c|c|c|c|}
\hline Year & $\begin{array}{c}\text { Non-Performing Loan (NPL) (N } \\
\text { Billion) }\end{array}$ & $\begin{array}{c}\text { Total Loan Granted } \\
\text { (N-Billion) }\end{array}$ & $\begin{array}{c}\text { Total Bank Assets } \\
\text { (N-Billion) }\end{array}$ & $\begin{array}{c}\text { Number of } \\
\text { Bank }\end{array}$ \\
\hline $\mathbf{2 0 0 6}$ & 225.08 & $2,840.1$ & $8,140.2$ & 25 \\
\hline $\mathbf{2 0 0 7}$ & N387.99 & $4,676.34$ & N13,011.6 & 24 \\
\hline $\mathbf{2 0 0 8}$ & N463.49 & $7,411.43$ & N19,251.02 & 24 \\
\hline $\mathbf{2 0 0 9}$ & $2,922.80$ & $8,912.14$ & $17,522.86$ & 24 \\
\hline $\mathbf{2 0 1 0}$ & $1,077.66$ & $7,166.76$ & $18,661.27$ & 24 \\
\hline $\mathbf{2 0 1 1}$ & 360.07 & $7,273.75$ & $21,891.56$ & 20 \\
\hline $\mathbf{2 0 1 2}$ & 286.09 & $8,150.03$ & $24,584.65$ & 20 \\
\hline
\end{tabular}

Source: NDIC Annual Reports and Statement of Accounts (2006-2012)Profitability Rations and ration of Nonperforming Loans to Total Loans granted

\begin{tabular}{|l|l|l|l|}
\hline Year & ROA & ROE & Ration of NPL To Total Loan \\
\hline $\mathbf{2 0 0 6}$ & 0.59 & 4.12 & $7.92 \%$ \\
\hline $\mathbf{2 0 0 7}$ & 5.92 & 36.83 & $8.30 \%$ \\
\hline $\mathbf{2 0 0 8}$ & 3.94 & 22.12 & $6.25 \%$ \\
\hline $\mathbf{2 0 0 9}$ & -9.28 & -64.72 & 32.8 \\
\hline $\mathbf{2 0 1 0}$ & 3.91 & 162.98 & 15.04 \\
\hline $\mathbf{2 0 1 1}$ & $(0.04)$ & $(0.28)$ & 4.95 \\
\hline $\mathbf{2 0 1 2}$ & 2.62 & 22.20 & 3.51 \\
\hline
\end{tabular}

Source: NDIC Annual Reports and Statement of Accounts (2006-2012)

Non-performing Loans, Total Loan granted, Ratio of NPL to Total Loans and Ratio of NPL to Shareholders funds in Nigeria 2006-2012

\begin{tabular}{|l|l|l|l|l|l|}
\hline Year & $\begin{array}{l}\text { Non-performing credit } \\
\text { (N Billion) }\end{array}$ & $\begin{array}{l}\text { total loan granted } \\
\text { (N Billion) }\end{array}$ & $\begin{array}{l}\text { Number } \\
\text { of bank }\end{array}$ & $\begin{array}{l}\text { Ratio of NPL to } \\
\text { Total Loan }\end{array}$ & $\begin{array}{l}\text { Ratio of NPL to } \\
\text { Shareholders fund }\end{array}$ \\
\hline $\mathbf{2 0 0 6}$ & 225.08 & $2,840.1$ & 25 & $7.92 \%$ & $22.06 \%$ \\
\hline $\mathbf{2 0 0 7}$ & 387.99 & $4,676.34$ & 24 & $8.30 \%$ & 22.66 \\
\hline $\mathbf{2 0 0 8}$ & 463.49 & $7,411.43$ & 24 & $6.25 \%$ & 16.62 \\
\hline $\mathbf{2 0 0 9}$ & $2,922.80$ & $8,912.14$ & 24 & 32.8 & 135.7 \\
\hline $\mathbf{2 0 1 0}$ & $1,077.66$ & $7,166.76$ & 24 & 15.04 & 250.85 \\
\hline $\mathbf{2 0 1 1}$ & 360.07 & $7,273.75$ & 20 & 4.95 & 17.13 \\
\hline $\mathbf{2 0 1 2}$ & 286.09 & $8,150.03$ & 20 & 3.51 & 14.34 \\
\hline
\end{tabular}

Source: NDIC Annual Reports and Statement of Accounts (2006-2012) 
From the above table we can see that in 2006 the non-performing loans is $\$ 225.08$ billion which represents $7.92 \%$ of the total loans and $22.06 \%$ of the shareholders' fund, 2007 had non-performing loans of $\$ 387.99$ billion resenting $8.30 \%$ of the total loan and $22.66 \%$ of shareholders' fund, the non-performing loans, in 2008 the non-performing loans stood at $\$ 463.49$ billion which is $6.25 \%$ of the total loan and 16.62 of the shareholders' fund. Even though there is reduction in the proportion of the non-performing loans to the total loan and the shareholders' fund there is increase in the value of non-performing loans from $\$ 387.99$ billion in 2007 to $\$ 463.49$ billion in 2008 which indicate an increase in the value of non-performing loans against what the percentages presented.

2009 financial year had highest amount of non- performing loans of $\$ 2,922.80$ billion followed by 2010 financial year with the sum of $\$ 1,077.66$ billion. The non-performing loans represent $32.8 \%$ and $15.04 \%$ of the total loan and $135.7 \%$ and $250.80 \%$ of the shareholders' fund in 2009 and 2010 respectively. The 2011 and 2012 financial years saw a reduction to $\$ 360.07$ billion and $\$ 286.19$ billion respectively which represents $4.95 \%$ of total loan and $17.13 \%$ of shareholders' fund in 2011 and $3.51 \%$ of total loan and $14.34 \%$ of shareholders' funds in 2012 .

\subsection{Test of Hypotheses}

Profitability Ratios, NPLs and Ration of Non-performing Loans to Total Loans granted

\begin{tabular}{|l|l|l|l|l|}
\hline Year & ROA & ROE & Non-performing credit (NPL) & NPL to Shareholders fund (SF) \\
\hline $\mathbf{2 0 0 6}$ & 0.59 & 4.12 & 225.08 & $22.06 \%$ \\
\hline $\mathbf{2 0 0 7}$ & 5.92 & 36.83 & 387.99 & 22.66 \\
\hline $\mathbf{2 0 0 8}$ & 3.94 & 22.12 & 463.49 & 16.62 \\
\hline $\mathbf{2 0 0 9}$ & -9.28 & -64.72 & $2,922.80$ & 135.7 \\
\hline $\mathbf{2 0 1 0}$ & 3.91 & 162.98 & $1,077.66$ & 25.85 \\
\hline $\mathbf{2 0 1 1}$ & $(0.04)$ & $(0.28)$ & 360.07 & 17.13 \\
\hline $\mathbf{2 0 1 2}$ & 2.62 & 22.20 & 286.09 & 14.34 \\
\hline
\end{tabular}

Source: NDIC Annual Reports and Statement of Accounts (2006-2012)

\section{Restatement of Hypothesis I}

Ho: There is no significant relationship between Non-performing Loans (NPL) and Return on Assets (ROA) of Nigerian Banks

\begin{tabular}{|c|c|c|c|c|c|c|c|c|}
\hline \multicolumn{9}{|c|}{ SUMMARY OUTPUT } \\
\hline \multicolumn{9}{|c|}{ Regression Statistics } \\
\hline Multiple R & 0.828246 & & & & & & & \\
\hline R Square & 0.685991 & & & & & & & \\
\hline $\begin{array}{ll}\text { Adjusted } & \text { R } \\
\text { Square } & \\
\end{array}$ & 0.623189 & & & & & & & \\
\hline Standard Error & 3.077506 & & & & & & & \\
\hline Observations & 7 & & & & & & & \\
\hline \multicolumn{9}{|l|}{ ANOVA } \\
\hline & $d f$ & $S S$ & $M S$ & $F$ & Significance $F$ & & & \\
\hline Regression & 1 & 103.4532 & 103.4532 & 10.9231 & 0.021357 & & & \\
\hline Residual & 5 & 47.35522 & 9.471043 & & & & & \\
\hline \multirow[t]{2}{*}{ Total } & 6 & 150.8084 & & & & & & \\
\hline & $\begin{array}{l}\text { Coefficien } \\
\text { ts }\end{array}$ & $\begin{array}{l}\text { Standard } \\
\text { Error }\end{array}$ & $t$ Stat & $P$-value & Lower $95 \%$ & $\begin{array}{l}\text { Upper } \\
95 \%\end{array}$ & $\begin{array}{l}\text { Lower } \\
95.0 \% \\
\end{array}$ & $\begin{array}{l}\text { Upper } \\
95.0 \% \\
\end{array}$ \\
\hline Intercept & 4.592092 & 1.572602 & 2.92006 & $\begin{array}{l}0.03301 \\
1\end{array}$ & 0.54959 & $\begin{array}{l}8.6345 \\
95\end{array}$ & $\begin{array}{l}0.5495 \\
9\end{array}$ & $\begin{array}{l}8.63459 \\
5\end{array}$ \\
\hline $\begin{array}{l}\text { Non- } \\
\text { performing } \\
\text { Loan (NPL|) }\end{array}$ & -0.00428 & 0.001294 & -3.30501 & $\begin{array}{l}0.02135 \\
7\end{array}$ & -0.00761 & $\begin{array}{l}- \\
0.0009 \\
5\end{array}$ & $\begin{array}{l}- \\
0.0076 \\
1\end{array}$ & $-\overline{0} 00095$ \\
\hline
\end{tabular}

Source: Microsoft Excel 2007

Decision: From the result of analysis above we found that the p value $(0.021357<0.05)$. The result of the analysis is an indication that there is a relationship between the tested variables. We therefore reject the null hypothesis that 
American Research Journal of Business and Management, Volume 1, Issue 4, 2015

ISSN 2379-1047

there is no significant relationship between Non-performing Loans (NPL) and Return on Assets (ROA) of Nigerian Banks. In other words, there is a relation between the Non-performing Loans (NPL) and Return on Assets (ROA) of Nigerian Banks.

\section{Restatement of Hypothesis II}

Ho: There is no significant relationship between Non-performing Loans (NPL) and Return on Equity (ROE) of Nigerian Banks

\begin{tabular}{|c|c|c|c|c|c|c|c|c|}
\hline \multicolumn{9}{|c|}{ SUMMARY OUTPUT } \\
\hline \multicolumn{9}{|c|}{ Regression Statistics } \\
\hline Multiple R & 0.823936 & & & & & & & \\
\hline R Square & 0.67887 & & & & & & & \\
\hline $\begin{array}{l}\text { Adjusted R } \\
\text { Square }\end{array}$ & 0.518306 & & & & & & & \\
\hline $\begin{array}{l}\text { Standard } \\
\text { Error }\end{array}$ & 47.67348 & & & & & & & \\
\hline $\begin{array}{l}\text { Observatio } \\
\text { ns }\end{array}$ & 7 & & & & & & & \\
\hline \multicolumn{9}{|l|}{ ANOVA } \\
\hline & $d f$ & $S S$ & $M S$ & $\boldsymbol{F}$ & $\begin{array}{l}\text { Significanc } \\
\text { e F }\end{array}$ & & & \\
\hline Regression & 2 & 19218.53 & $\begin{array}{l}9609.26 \\
5\end{array}$ & $\begin{array}{l}4.228 \\
015\end{array}$ & 0.103124 & & & \\
\hline Residual & 4 & 9091.041 & 2272.76 & & & & & \\
\hline \multirow[t]{2}{*}{ Total } & 6 & 28309.57 & & & & & & \\
\hline & $\begin{array}{l}\text { Coefficie } \\
\text { nts }\end{array}$ & $\begin{array}{l}\text { Standard } \\
\text { Error }\end{array}$ & $t$ Stat & $\begin{array}{l}P \text { - } \\
\text { value }\end{array}$ & Lower $95 \%$ & $\begin{array}{l}\text { Upper } \\
95 \%\end{array}$ & $\begin{array}{l}\text { Lower } \\
95.0 \%\end{array}$ & $\begin{array}{l}\text { Upper } \\
95.0 \%\end{array}$ \\
\hline Intercept & 21.11152 & 25.98522 & $\begin{array}{l}0.81244 \\
3\end{array}$ & $\begin{array}{l}0.462 \\
122\end{array}$ & -51.035 & $\begin{array}{l}93.2580 \\
6\end{array}$ & -51.035 & 93.25806 \\
\hline $\begin{array}{l}\text { Ratio of } \\
\text { NPL to SF }\end{array}$ & -5.28337 & 1.981799 & $-\overline{2.66595}$ & $\begin{array}{l}0.056 \\
042\end{array}$ & -10.7857 & $\begin{array}{l}0.21898 \\
7\end{array}$ & -10.7857 & 0.218987 \\
\hline NPL & 0.220849 & 0.093746 & $\begin{array}{l}2.35583 \\
1\end{array}$ & $\begin{array}{l}0.078 \\
017\end{array}$ & -0.03943 & 0.48113 & -0.03943 & 0.48113 \\
\hline
\end{tabular}

Source: Microsoft Excel 2007

Decision: Since the p value $(0.056042 \& 0.078017>0.05)$. The result is an indication that a relationship subsist between the tested variables. We therefore accept the null hypothesis that there is no significant relationship between Non-performing Loans (NPL) and Return on Equity (ROE) of Nigerian Banks. In other words, there is no relation between the Non-performing Loans (NPL) and Return on Equity (ROE) of Nigerian Banks.

\section{CONCLUSION AND RECOMMENDATION}

Although there is no relationship between the Non-performing Loans (NPL) and Return on Assets (ROA) of Nigerian Banks which means that the asset value of the firms are not affected by the level of NPL, the shareholders wealth maximization is affected since the result above shows that there is a relation between the Non-performing Loans (NPL) and Return on Assets (ROE) of Nigerian Banks.

Therefore, we recommend the following steps be taken into consideration:

$>$ To solve the challenge of non-performing loan, we suggest that the banks should ensure that the banks customer has viable means of repayment. Also they bank can offer professional advice to the loan collector on passible means of efficiently investing the loan to ensure the needed return on investment is attained.

$>$ The banks should ensure that customers who collects loan maintain proper account record from which they can monitor the progress of the customer's business in comparison with what is expected. This will help the bank know when the customer's business is not performing in order to take necessary action before it is late. 
It is of great importance that the NPL be further checked to ensure that investors in the banking industry are not discouraged from investing or even divert their investments.

That a standard be set on the minimum value of collateral in relation to the amount of money being loaned to a customer.

$>$ There should be electronic platforms to check if an asset has been used as collateral by a customer to lend money from other sources (fund providers).

$>$ There should be severe punishments to defaulter of bank loan that mostly lead to NPLs.

There should be a form of penalty on the bank with the highest amount of NPL and a reward for the bank with the lowest amount of NPL.

\section{REFERENCES}

Abdullahi S. R. (2013), Efficacy of Credit Risk Management on the Performance of Banks in Nigeria A Study of Union Bank PLC (2006-2010). Global Journal of Management and Business Research Administration and Management Volume 13

Ayo, V. (2002), Management Accounting: Ibadan. Dikasinma Publishers

Bossone B (2001), Do banks have a future? A study on banking and finance as we move into the third millennium Journal of Banking \& Finance 25, 2239-2276

Caprio G Jr and Klingebiel D (1996), Bank Insolvency: Bad Luck, Bad Policy or Bad Banking, Annual World Bank Conference on Development Economics.

Greuning H and Bratanovic S.B (2003), Analyzing and Managing Banking Risk: A Framework for Assessing Corporate Governance and Financial Risk. 2nd edition, The World Bank, Washington DC

Hennie V. G (2003), Analyzing and Managing Banking Risk: A Framework for Assessing Corporate Governance and Financial Risk, 2nd Edition, Washington DC: World Bank Publications.

Jimenez G and Saurina J (2005), “Credit cycles, credit risk, and prudential regulation”, Banco de Espana, May 2007, Contemporary Research in Business

Joseph, M.T., Edson, G., Manuere, F., Clifford, M., and Michael, K. (2012), Non Performing Loans in Commercial Banks: A Case Of CBZ Bank Limited 27 In Zimbabwe. Interdisciplinary Journal of Contemporary Research In Business, Vol. 4 (7).

Khalid A. (2012), The impact of Asset Quality on Profitability of Private Banks in India: A Case Study of JK, ICICI, HDFC \& YES Banks. Journal of African Macroeconomic Review Vol. 2, No. 1

Khan, M.S. and S.A. Senhadji (2001), Threshold Effects in the Relationship between Inflation and Growth IMF Staff Papers, Vol. 48, No. 1

Mohammed, F. (2012) Impact of Corporate Governance on Banks Performance in Nigeria. Journal of Emerging Trends in Economics and Management Sciences (JETEMS) 3(3): 257-260

Nir Klein (2013) Non-Performing Loans in CESEE: Determinants and Macroeconomic Performance. IMF Working Paper

Rajiv R and Dhal S C (2003), "Non-performing Loans and Terms of Credit of Public Sector Banks in India: An Empirical Assessment" Occasional Papers, 24:3, pp 81-121, Reserve Bank of India

Roberto A. De Santis and Paolo S. (2013) Bank Lending and Monetary Transmission in the Euro Area, Working Paper Series No. 1568 of the European Central Bank (ECB)

Subaru G, Nafiu A and Omankhanlen O, (2011). CBN Grants New Licenses to 17 Banks, Nigerian Tribune Newspaper, June 1, pp 53. 